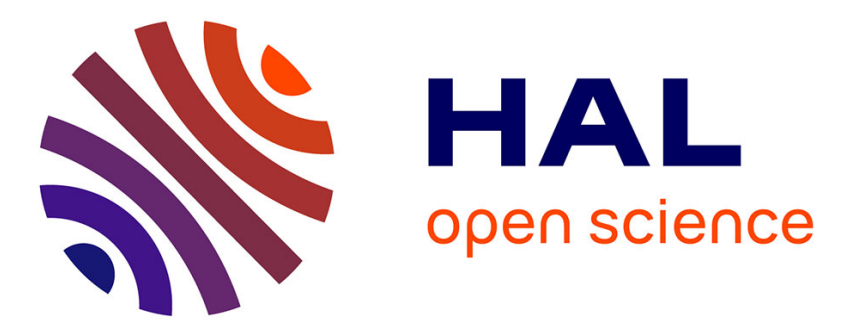

\title{
Reconstruction of erosivity density in northwest Italy since 1701
}

Nazzareno Diodato, Iñigo Gómara, Alice Baronetti, Simona Fratianni, Gianni Bellocchi

\section{- To cite this version:}

Nazzareno Diodato, Iñigo Gómara, Alice Baronetti, Simona Fratianni, Gianni Bellocchi. Reconstruction of erosivity density in northwest Italy since 1701. Hydrological Sciences Journal, 2021, pp.1-12. 10.1080/02626667.2021.1918696 . hal-03263455

\section{HAL Id: hal-03263455 \\ https://hal.inrae.fr/hal-03263455}

Submitted on 17 Jun 2021

HAL is a multi-disciplinary open access archive for the deposit and dissemination of scientific research documents, whether they are published or not. The documents may come from teaching and research institutions in France or abroad, or from public or private research centers.
L'archive ouverte pluridisciplinaire HAL, est destinée au dépôt et à la diffusion de documents scientifiques de niveau recherche, publiés ou non, émanant des établissements d'enseignement et de recherche français ou étrangers, des laboratoires publics ou privés.

\section{(ㅇ)(1) $\$$}

Distributed under a Creative Commons Attribution - NonCommercial - NoDerivatives| 4.0 


\section{Hydrological Sciences Journal}

\section{Reconstruction of erosivity density in northwest Italy since 1701}

\section{Nazzareno Diodato, Iñigo Gómara, Alice Baronetti, Simona Fratianni \& Gianni Bellocchi}

To cite this article: Nazzareno Diodato, Iñigo Gómara, Alice Baronetti, Simona Fratianni \& Gianni Bellocchi (2021): Reconstruction of erosivity density in northwest Italy since 1701, Hydrological Sciences Journal, DOI: 10.1080/02626667.2021.1918696

To link to this article: https://doi.org/10.1080/02626667.2021.1918696

册Published online: 03 Jun 2021.

Submit your article to this journal ๘

山 Article views: 36

Q View related articles $\asymp$

View Crossmark data $₫$ 


\title{
Reconstruction of erosivity density in northwest Italy since 1701
}

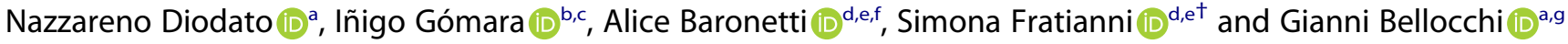 \\ ${ }^{a}$ Met European Research Observatory, International Affiliates Program of the University Corporation for Atmospheric Research, Benevento, Italy;

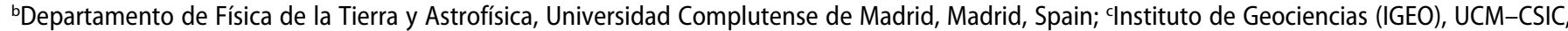

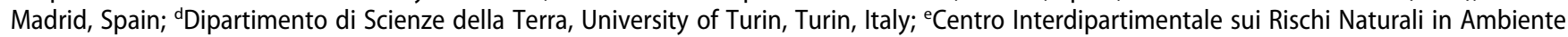 \\ Montano e Collinare, University of Turin, Turin, Italy; fIstituto di Geoscienze e Georisorse, Consiglio Nazionale delle Ricerche, Pisa, Italy; ${ }^{9}$ Université \\ Clermont Auvergne, INRAE, VetAgro Sup, UREP, Clermont-Ferrand, France
}

\begin{abstract}
Societies can be better prepared to face hydrological extremes (e.g. flash floods) by understanding the trends and variability of rainfall aggressiveness and its derivative, erosivity density (ED). Estimating extended time series of ED is, however, scientifically challenging because of the paucity of long-term high-resolution pluviometric observations. This research presents the longest ED time series reconstruction (1701-2019) in northwest Italy (Piedmont region) to date, which is analysed to identify damaging hydrological periods. With this aim, we developed a model consistent with a sample (1981-2015) of detailed novel Revised Universal Soil Loss Erosion-based high-resolution data and documentary hydrological extreme records. The modelled data show a noticeable rising trend in ED from 1897 onwards, together with an increase of extreme values for return periods of 10 and 50 years, consistent with the Clausius-Clapeyron scaling of extreme rainfall. We also suggest the North Atlantic Oscillation and Atlantic Multidecadal Oscillation may be associated with rainfall extremes in Piedmont.
\end{abstract}

ARTICLE HISTORY

Received 14 October 2020

Accepted 9 March 2021

EDITOR

S. Archfield

ASSOCIATE EDITOR

J. Rodrigo-Comino

KEYWORDS

erosivity density; long-term reconstruction; parsimonious modelling; extreme precipitation; Piedmont; Italy

\section{Introduction}

Worldwide variations in temperature and precipitation patterns produce corresponding changes in the development of natural hazards (Brönnimann et al. 2018). For instance, water is a precious resource for terrestrial ecosystems, but it can also turn into a land-disturbing factor due to the erosive force of rainfall, expressed as rainfall (storm) erosivity, or R-factor, in the Universal Soil Loss Equation (USLE) by Wischmeier and Smith (1978) and its revised - (R)USLE - versions (Brown and Foster 1987, Renard and Freimund 1994, Renard et al. 1997). Rainfall erosivity is a major driver of soil sediment and nutrient losses worldwide, which may leave farmers vulnerable to crop failures and lead to landscape degradation (Panagos et al. 2017a, Wuepper et al. 2020). The exposure of the Earth's surface to heavy rainfall is a key factor controlling water erosion in terrestrial ecosystems (Li and Fang 2016) and other damaging hydrological events, such as floods and flash floods (Diodato et al. 2019). It is also assumed that extreme storms and rainfall-runoff erosivity are becoming more frequent due to anthropogenic climate change, as warmer air is capable of holding more moisture-feeding rainfall events, also known as Clausius-Clapeyron scaling of extreme rainfall (Trenberth et al. 2003, Westra et al. 2014, Yin et al. 2018).

Long-term reconstructions of rainfall erosivity can help to disentangle the role of anthropogenic climate change and the natural variability of the climate system in heavy rainfall events and floods (Diodato et al. 2020a, 2020b). The latter, through atmospheric-oceanic teleconnection patterns such as El Niño
Southern Oscillation (ENSO), the North Atlantic Oscillation (NAO), the Atlantic Multidecadal Oscillation (AMO) and the Pacific Decadal Oscillation (PDO), can drive the frequency and intensity of regional rainfall events worldwide (Wetter et al. 2011, Willems 2013, Gómara et al. 2018, Diakhaté et al. 2019). The NAO is the most prominent pattern influencing weather and climate variability and precipitation extremes in Europe from synoptic to millennial time scales (Pinto and Raible 2012, Casanueva et al. 2014, Gómara et al. 2016). It consists of a mean sea level pressure dipole pattern between subtropical and subpolar North Atlantic areas and characterizes the intensity and location of the westerly flow. At multidecadal time scales the AMO and PDO, which are warming/cooling patterns of North Atlantic and North Pacific sea surface temperatures (SSTs) with $\sim 40 / 60$-year periodicities, are also known to influence European surface temperatures and precipitation regimes, including northwest Italy (Sutton and Dong 2012, Diodato and Bellocchi 2014).

Long-term reconstructions of extreme rainfall events can also provide a better insight into their disturbing impacts on ecosystem functioning and economic security (Harris et al. 2018). Historical studies have identified flood-rich and erosive periods, e.g. over the $17^{\text {th }}$ and $18^{\text {th }}$ centuries, characterized by flooding and heavy runoff at most European sites (Longman et al. 2019, Blöschl et al. 2020). Thus, understanding and forecasting long-term hydro-climate variability is important to better comprehend environmental changes such as runoff and soil loss. 
In Europe, water-driven soil erosion is a major environmental threat (Boardman and Poesen 2006). Using a unique, seasonally resolved lake record from southern Europe, Corella et al. (2016) quantified subdecadal changes in extreme heavy rainfall events for the last 2800 years in northeast Spain, and their correlation with negative phases of the Mediterranean Oscillation Index. Taricco et al. (2015) used a multidecadalresolution foraminiferal $\delta^{18} \mathrm{O}$ record from a sediment core in the Ionian Sea to reconstruct millennium-scale hydrological variability in northern Italy. On shorter time scales, erosive forcing increased towards the end of the Little Ice Age ( 1850) across the western and central Mediterranean, concurrent with a higher occurrence of intense storms in lowlands (Diodato and Bellocchi 2010, Diodato et al. 2011). All these changes are critical because they increase pressure on soil erosion and are hard to predict and prevent. Improved knowledge and understanding of these changes are thus essential for dealing with the challenges that soil and water conservation practices face (Wei et al. 2009). Today, soil erosion and sediment losses are causing major and widespread environmental degradation worldwide (Millares and Moñino 2020). A decrease in agricultural productivity due to the removal of fertile topsoil is one of the main consequences of sediment dynamics, which may require improved drainage systems for flood management (Castellano et al. 2019) and a transition to more sustainable practices in rural areas (Piñeiro et al. 2020).

Accurate and time-consuming rainfall measurements on short time scales (e.g. minutes) are required to obtain stormerosivity values according to the (R)USLE methodology (Renard et al. 1997) or similar procedures (Panagos et al. 2015). However, this is problematic for long-term studies because records of this type are not available before the modern instrumental period (Diodato and Bellocchi 2010, 2014). This perspective presents climate and environmental historians with a challenge to provide valuable information drawn from historical records in order to better explain and model past erosivity dynamics (Pfister et al. 2018). The variability observed in erosive rainfall and the difficulties experienced in the parameterization and operational use of complex erosivity models justify efforts to develop simple methods to predict erosivity (Quinton 2004).

In this research, we address this issue by focusing on the Piedmont region in northwest Italy, and using the erosivity density (ED), i.e. the ratio of rainfall erosivity to precipitation, as a proxy of the rainfall erosive hazard (Renard et al. 2011). A precipitation dataset was recently released for this region, and data were published for 12 stations over 30 years at a 10minute time resolution (Acquaotta et al. 2019). Based on this novel set of data, we developed and assessed a parsimonious rainfall erosivity model for estimating the related ED. Then we reconstructed, for the first time in Piedmont, regional changes in ED back in time to 1701, by running the parsimonious model with the long-term European precipitation reconstruction dataset provided by Pauling et al. (2006).

Although Acquaotta et al. (2019) quantified rainfall erosivity in Piedmont for the period 1989-2015, there is a particular interest in investigating long-term variability and trends of erosive precipitation in the region. This is because in northwest Italy, geomorphology is an important factor shaping the water height and flooded areas (Giordan et al. 2018). In addition, extreme erosive events have several especially significant practical consequences, in areas such as agriculture (e.g. field crop destruction) and water resource management. In fact, Piedmont's economy is highly dependent on agriculture, with the cultivation of high-quality food products such as hazelnut and wine grape. There has been a strong expansion of the cultivation of hazelnut since the 1900s because of the increasing demand of the confectionery industry, with the discovery of the sweet spread gianduja (Oddone et al. 2009). Also, Piedmont is Italy's eighth largest wine-producing region, with more than 40000 ha devoted to wine grape production (ISTAT 2020). Mainly located over hilly areas, vineyards are established on highly erodible soils exposed to aggressive rainfall episodes (Corti et al. 2011). Indeed, of all cultivated lands, vineyards suffer the greatest soil losses due to water erosion (Prosdocimi et al. 2016), aggravated by their location on steep slopes (Arnaez et al. 2007). Disentangling the role played by natural variability and anthropogenic climate change in driving aggressive rainfall may help to illuminate ED dynamics in the region, and thus support disaster risk preparedness and resilience for the decades to come.

Here, we used amounts of seasonal precipitation and data on weather anomalies to develop a simple, climatically interpretable model for reconstructing annual erosivity data in Piedmont over the period 1701-2019. For both its length and spatial extension, this provided an unprecedented time series to capture and communicate the erosivity hazard in northwest Italy.

\section{Data and methods}

\subsection{Study area}

Piedmont is located in the northwestern sector of Italy (Fig. 1). It is bounded on the north, west and southwest by the Alps, and on the south and southeast by the Apennines. The region is covered by extensive mountainous areas (43\%), hills (30\%) and plains (27\%). According to the Köppen classification (Rubel et al. 2017), continental climate (Cf) is the main climate observed in northern Italy (Pinna 1978). Specifically, climate is humid subtropical with hot summer (Cfa) in the plain, and temperate oceanic $(\mathrm{Cfb})$ in the hills and foothills (Fratianni and Acquaotta 2017). Cold temperate climate (Dw) characterizes the mountain chain. Orographic configuration enhances the onset of foehn winds, typically occurring in the northwestern sectors with airflows coming from the north, northwest and west, and less frequently in the southern sectors (Fratianni et al. 2009).

Due to the complex orography (Fig. 2) and different microclimate conditions, precipitation is unevenly distributed in space and time. Baronetti et al. (2018) identified five subclimatic areas. The two driest sectors are located in the Po Plain, with annual precipitation between 600 and $1000 \mathrm{~mm} \mathrm{year}^{-1}$. The three rainiest areas are along the mountain range. One is to the north, with annual precipitation amounts greater than $2000 \mathrm{~mm}$ year $^{-1}$. To the northwest, annual precipitation rates are 1700 $1900 \mathrm{~mm} \mathrm{year}^{-1}$ (except for Susa Valley, surrounded by high mountain peaks, where precipitation reaches only $600 \mathrm{~mm}$ year $\left.^{-1}\right)$. To the southeast, at the foothills of the Ligurian 

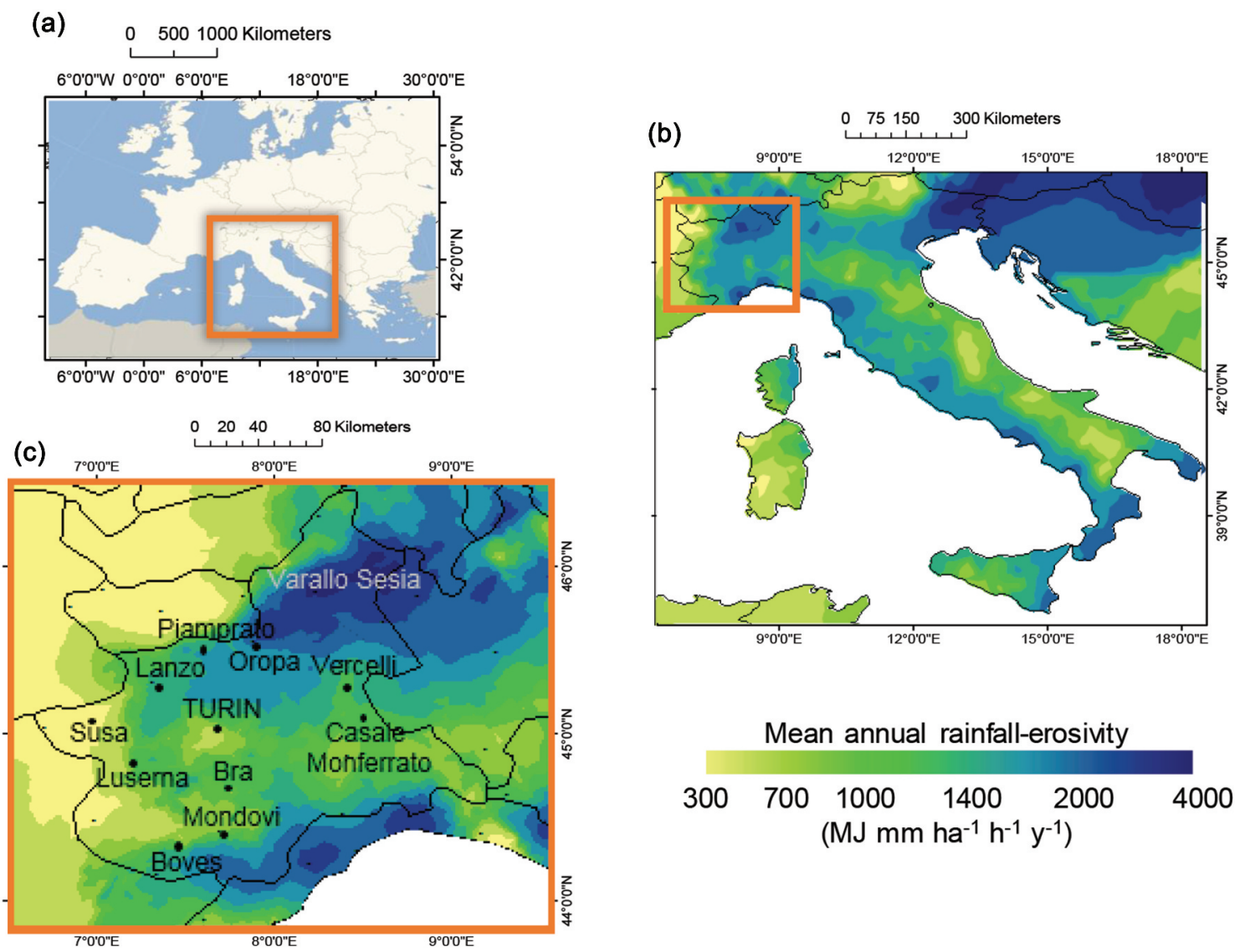

Figure 1. (a) Geographical setting and (b) detrended kriged map of mean annual rainfall erosivity across Italy (2001-2010), with (c) the refinement for the Piedmont region using a co-kriged approach with precipitation as secondary information. Maps arranged by ArcMap - Environmental Systems Research Institute (ESRI) using data provided by Rainfall Erosivity Database at European Scale (REDES) database.

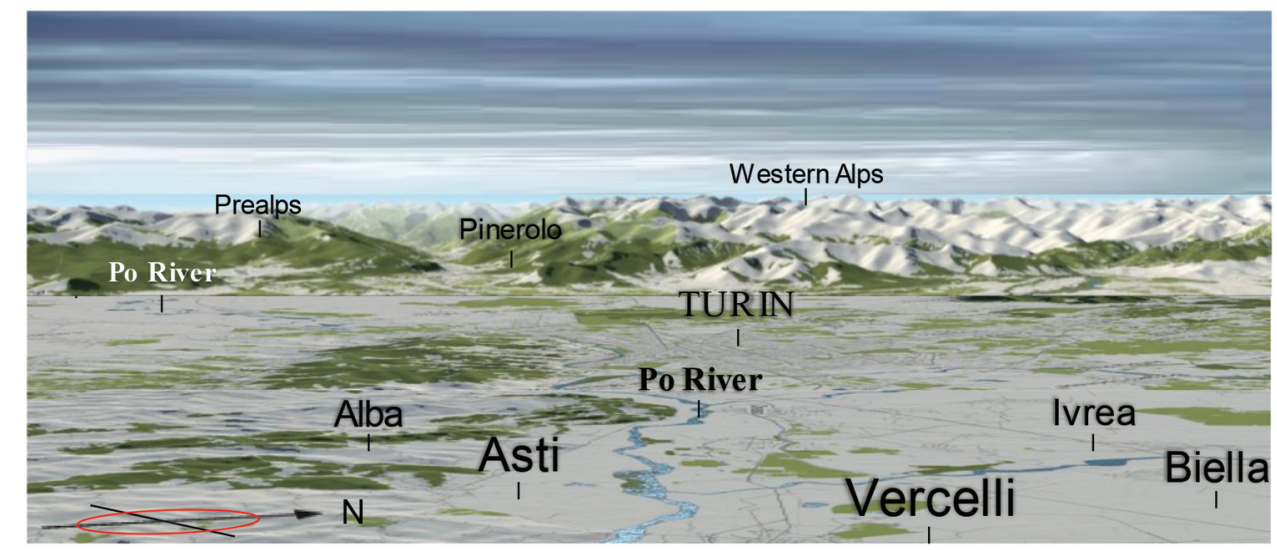

Figure 2. Perspective of Piedmont area from the east. The Po River winds through the landscape, passing through the city of Turin after leaving its source in the Alps (created using OpenStreet Map, https://demo.f4map.com).

Apennines, rainfall is between 670 and $1800 \mathrm{~mm} \mathrm{year}^{-1}$. In Northern Italy, although the Alps have the highest mean daily rainfall intensity, of $92.6 \mathrm{~mm} \mathrm{~d}^{-1}$ (compared to the $52.2 \mathrm{~mm} \mathrm{~d}^{-1}$ in the Po Plain), extreme precipitation events mostly occur in the driest sectors of the Po Plain, especially during autumn (when moisture supply from warm Mediterranean waters is maximum). This exposes the central Piedmont sector to considerable soil loss by water erosion (Acquaotta et al. 2019).

\subsection{Data}

The following datasets were utilized in this study:

- Piedmont 10-min fixed-interval rainfall data: 10-min rainfall data were obtained from Agenzia Regionale per la Protezione Ambientale (ARPA), from 12 electronic raingauge stations homogeneously distributed over the Piedmont region: Turin, Boves, Bra, Casale Monferrato, 
Lanzo, Luserna, Mondovì, Oropa, Piamprato, Susa, Varallo Sesia and Vercelli (Fig. 1(c)). Annual rainfall erosivity data were extracted for the period covered by the database (1981-2015). Specific details on rainfallerosivity data calculations are available in Acquaotta et al. (2019).

- Long-term gridded high-resolution precipitation reconstruction over Europe: The 500-year precipitation reconstruction dataset from Pauling et al. (2006) was utilized. This dataset is seasonally resolved from 2000 back to 1500 , covering most European land areas $\left(30-71^{\circ} \mathrm{N}, 30^{\circ}\right.$ $\mathrm{W}-40^{\circ} \mathrm{E}$ ) on a $0.5^{\circ}$ horizontal grid. We used 1701 data onwards because precipitation data for earlier times were reconstructed from non-instrumental proxies only and, as such, were affected by larger uncertainties.

- Annual severity storm index sum (ASSIS): A categorical variable, the annual severity storm index sum (ASSIS), was derived from Diodato et al. (2020c) to overcome the lack of historical information about rain intensity. ASSIS was developed based on several written sources, by transforming documentary information into a record set to 0 (normal event), 1 (stormy event), 2 (very stormy event), 3 (great stormy event) or 4 (extraordinary stormy event).

- The Climate Research Unit (CRU) Global Climate Dataset: It provided for an extension of the seasonal precipitation dataset from 2001 to 2019 for ED reconstruction over Piedmont. CRU data are provided at $0.5^{\circ}$ resolution on a monthly basis (Harris et al. 2020).

- Last Millennium Reanalysis (LMR) Project Global Climate Reconstructions Version 2: Annually resolved ensemble mean gridded fields $\left(2^{\circ}\right.$ resolution) and climate indices were retrieved for the period 1701-2000 to analyse ED trends and variability. Additional information on the set of assimilated proxy records is available in Tardif et al. (2019).

- The NOAA Twentieth Century reanalysis (20CR): The NOAA (National Oceanic and Atmospheric Administration) $20 \mathrm{CR}$ was utilized to analyse $\mathrm{ED}$ variability for the more recent period 1871-2009. Data are available at $2^{\circ}$ horizontal resolution at 24 vertical pressure levels (Compo et al. 2011).

- The sea surface temperature (SST) and sea ice data from the Met Office Hadley Centre (HadISST): This is a monthly $1^{\circ}$ gridded global dataset starting in 1870 (Rayner et al. 2003). It was utilized to analyse SST forcing on ED variability.

- Total sunspot number from Sunspot Index and Longterm Solar Observations (SILSO): Yearly mean total sunspot numbers for the period 1700-2019 were retrieved from SILSO (http://www.sidc.be/silso/datafiles).

- Geomagnetic activity aa (Kpa) index from the International Service of Geomagnetic Indices (ISGI): This index was retrieved from ISGI (http://isgi.unistra. fr/indices_aa.php) to analyse the polarity of sunspot activity (Hale and Nicholson 1938) and ED variability for the period 1901-2009.

Complementary datasets were also generated describing rainfall erosivity from the REDES (Rainfall Erosivity Database at European Scale) database (Panagos et al. 2017b) and NASA (National Aeronautics and Space Administration)satellite web-based convective rain fluxes over Italy for the period 1979-2015 (http://disc.sci.gsfc.nasa.gov/giovanni).

\subsection{Model development}

We first acquired a comprehensive knowledge of factors potentially driving rainfall erosivity in Piedmont, where highintensity rainfall occurs mainly in summer and autumn due to the prevalence of thunderstorms during this part of the year. Occasionally, however, high-intensity rainfall may occur in the winter half-year associated with the atmospheric flow over the North Atlantic and Mediterranean region, originating from the contrast between tropical and extratropical latitudes (Pinto et al. 2001). Then, an iterative process (trial and error to compose relevant drivers) enabled us to explain long-term dynamics in relatively simple terms that is, the principle of parsimony or explaining classes of events with a limited number of factors. In this way, we built a model of rainfall erosivity on an initial simple structure, while gradually and thoroughly enriching it as needed to improve model performance, by matching the following criteria:

$$
\left\{\begin{array}{c}
R^{2}=\max \\
M A E=\min \\
|b-1|=\min
\end{array}\right.
$$

These three criteria constrain the performance of the model. The mean absolute error (MAE, MJ ha ${ }^{-1} \mathrm{~h}^{-1}$ year $^{-1}$ ) was used to quantify the differences between actual and modelled erosivity values, while the coefficient of determination $\left(0 \leq R^{2} \leq 1\right.$, optimum), the related Pearson correlation coefficient $(-1 \leq r$ $\leq 1$, optimum) and the slope ( $b=1$, optimum) were used to assess the linear relationship between the two series. Poor models are characterized by high MAE, low $R^{2}(r)$ and $b$ far from unity.

The estimated annual erosivity density $(E D e)$ was obtained by dividing the modelled rainfall erosivity $(R a-m o d)$ by the related annual precipitation $(\mathrm{Pa})$ :

$$
E D e=\frac{R_{a-m o d}}{P a}
$$

Ra-mod was derived from a parsimonious nonlinear equation:

$$
R_{a-\bmod }=A \cdot([\alpha \cdot P w i n+P s p r+(1+\beta) \cdot(\text { Psum }+ \text { Paut })])
$$

where $R a$-mod is the average estimate of annual rainfall erosivity (M) mm ha ${ }^{-1} \mathrm{~h}^{-1}$ year $^{-1}$ ) for the Piedmont region; $A$ is a scale parameter, and Psum, Paut, Pwin and Pspr are the seasonal precipitation amounts ( $\mathrm{mm}$ ) for summer (June-August), autumn (September-November), winter (December-February) and spring (March-May), respectively. The first process factor $\alpha$ is:

$$
\alpha=0.094+\operatorname{ASSIS}(G F)
$$

In this way, the Gaussian filtered annual storm severity index

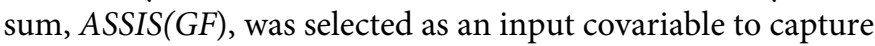
storm energy in winter. The multiplicative component $\alpha \cdot$ Pwin 
(Equation 4) supports the nonlinear dependence of rainfall erosivity on precipitation intensity (D' Odorico et al. 2001). The original ASSIS time series of yearly values (Diodato et al. 2020c) was smoothed by applying the low-pass Gaussian filtering technique described by Gjelten et al. (2016). Weighting coefficients $\left(w_{i j}\right)$ were applied to derive the Gaussian function, $\operatorname{ASSIS}(G F)$, for each year $j$ :

$$
\operatorname{ASSIS}(G F)=\frac{\sum_{i=1}^{n} w_{i j} \cdot x_{i}}{\sum_{i=1}^{n} w_{i j}} \text { with } w_{i j}=e^{\frac{-(i-j)^{2}}{2 \cdot \sigma^{2}}}
$$

where $x_{i}$ is the data point at year $i, \sigma$ is the standard deviation, and $n$ is the number of years in the series. The series of filtered values is established by letting $j$ run through all data points. To remove variations at smaller time scales than approximately 10 data points in the time series, an 11-year window $(i-j)$ and $\sigma=3$ years were chosen (Harris et al. 2003).

Summer and autumn precipitation amounts, generally characterized by a high intrinsic variability, were set to be modulated by the factor $\beta$ (Equation 6), which is a modified version of the variation coefficient from Aronica and Ferro (1997):

$$
\beta=\gamma+\left(\frac{S D}{\operatorname{Max}(P s)}\right)^{\eta}
$$

where $S D$ is the standard deviation of seasonal precipitations, and $\operatorname{Max}(\mathrm{Ps})$ is the seasonal maximum precipitation in a year, while $\gamma$ and $\eta$ are process parameters modulating the power of rainfall in any season.

In addition to the above evaluation criteria (Equation 1), we used the index of agreement (IA) of Willmott (1981), a standardized measure of the degree of model prediction error between 0 and 1 (optimum) and the Durbin-Watson statistic (Durbin and Watson 1950, 1951) to test for autocorrelated residuals against large temporal dependence inducing spurious correlations (Granger et al. 2001). The analysis of variance (ANOVA) $p$ value was used to present the statistical significance of the regression between estimates and the actual data.

\subsection{Model assumptions}

The rationale behind Equation (2) is that two main processes are relevant for storm-erosivity generation: power of rainfall by seasonally variable erosive-storm events, and runoff erosivity. The product of the first term accounts for the storm severity index ASSIS(GF) and winter precipitation amounts. In wintertime, Piedmont precipitation is mainly caused by large-scale fronts of North Atlantic and Mediterranean synoptic low-pressure systems, which produce moderate but continuous rainfall (Hawcroft et al. 2012). When the severity index is greater than 1 , slight changes in winter precipitation produce proportionally greater changes in the likelihood of erosive rainfall occurrence.

Convective spring and summer heavy precipitations are the most important drivers of rainfall-runoff processes over Piedmont (Diodato and Soriano 2014, Acquaotta et al. 2019). In particular, the second process (essentially reflected by spring precipitation amounts) is modulated by a constant parameter.

The product of the third term is interpreted by the interaction between a power factor (exponent $\eta$ ), a modified variation coefficient of precipitation within the year (which is higher when season-to-season rainfall variability is higher), and the summer-autumn precipitation (Aronica and Ferro 1997). The underlying assumptions reflect the climatology of northern Italy, where high-intensity rainstorms generally occur in a period between end of spring and beginning of autumn (Taszarek et al. 2018).

\subsection{Model evaluation}

The calibrated parameters are: $A=1.470$ in Equation (3), $\gamma=2.71$ and $\eta=8$ in Equation (6). This parameterization matches the actual data (Fig. 3(a)). The regression is statistically significant $(p$ value $<0.05)$, and the evaluation metrics $r=0.85, I A=0.91$ and $M A E=238 \mathrm{MJ} \mathrm{mm} \mathrm{ha}{ }^{-1} \mathrm{~h}^{-1}$ year $^{-1}$ indicate that the model of rainfall erosivity is robust and can (a)

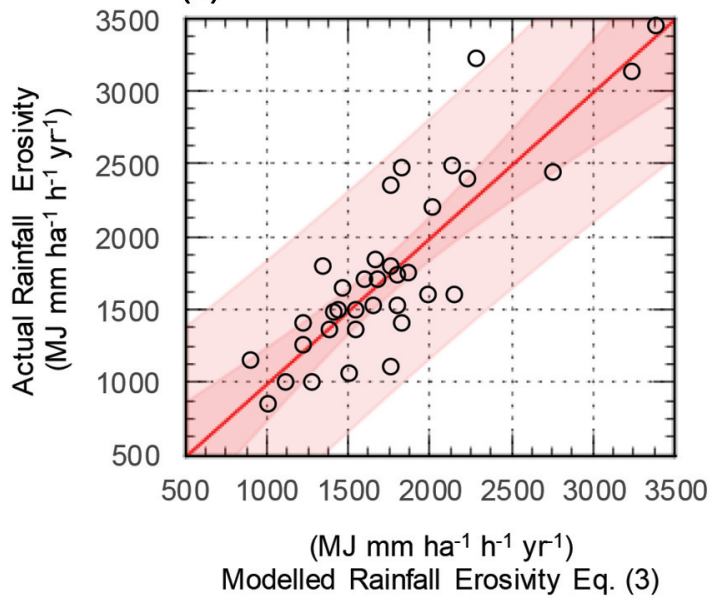

(b)

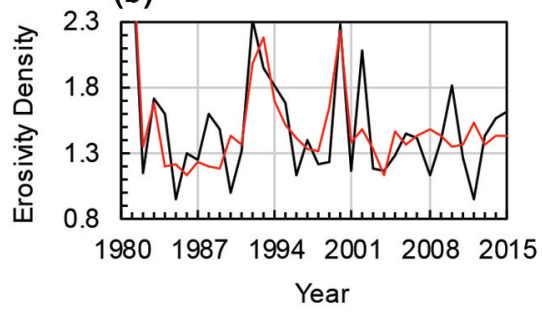

c)

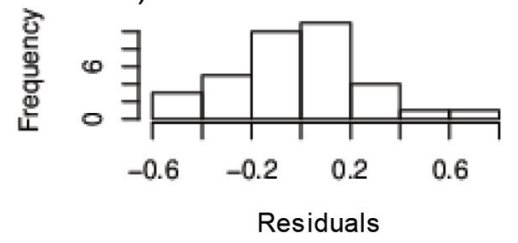

Figure 3. (a) Scatterplot between actual and modelled rainfall erosivity, with the corresponding $95 \%$ (light pink band) and the inner $99 \%$ (pink band) prediction bounds, and 1:1 line; and (b) co-evolution of actual (black curve) and estimated (red curve) erosivity density data during the 1981-2015 period, with (c) the respective residuals (errors) histogram. 
reasonably be used in Equation (2) as predictor of erosivity density in Piedmont (Fig. 3(b)).

The residuals show a skewness-free pattern compatible with a Gaussian distribution (Fig. 3(c)). The Durbin-Watson (DW) $p$ value being greater than $0.05-\mathrm{DW}$ statistic $=2.3617$ $(p$ value $=0.8459)-$ indicates there is no sign of serial autocorrelation in the residuals at the $95 \%$ confidence level. We deduce that Equation (2) is a suitable estimator of erosivity density in individual years and may capture patterns of erosivity density at intra- and interdecadal time scales.

\subsection{Trend assessment of extreme values}

The quantile approach was applied to identify step trends at any $\mathrm{ED}_{X}$ scheme with the assigned return periods (10 and 50 years; hereafter RP10 and RP50). The return period (T) for the seasonal rainfall erosivity density falling above the $j^{\text {th }}$ quantile was ranked using the lognormal distribution, according to Aronica and Ferro (1997):

$$
Q\left(E D_{X t-w}\right)_{T}=\exp \left[\mu\left(E D_{X t-w}^{*}\right)+u_{T} . \sigma\left(E D_{X t-w}^{*}\right)\right]
$$

where $Q\left(E D_{X t-w}\right)_{T}$ is the $j^{\text {th }}$ rainfall erosivity density $\left(E D_{X}\right)$ quantile of the lognormal distribution with assigned return period; $\mu\left(E D_{X t-w}^{*}\right)$ and $\sigma\left(E D_{X t-w}^{*}\right)$ are the mean and the standard deviation of the variable $E D_{X}{ }^{*}=\ln \left(E D_{X t}\right)$. The subscript $t-w$ indicates the computation of the generic variable at the time $t$ over a 22-year moving window $(w) ; u_{T}$ is the lognormal dimensionless coefficient, which is equal to 0.50 for $T$ $=10$ years and 2.05 for $T=50$ years (Diodato 2004).

The moving window of 22 years proved effective to show long-term trends by smoothing out the secular variation and the more volatile year-to-year changes (Perrier et al. 2005, Diodato and Bellocchi 2010). It reflects the $\sim 22$-year magnetic polarity cycle of sunspot activity (Hale et al. 1919). Solar-like periodicities suggest that the Sun may be one of the precursors of hydrological processes in northern Italy, which involve the magnetic activity of sunspots (Zanchettin et al. 2008a).

The Mann-Kendall (M-K) test (Kendall 1975) was utilized to statistically assess monotonic upward or downward trends in the data over time. Both parametric Buishand (1982) and nonparametric Manley-Whitney-Pettit (1979) tests were utilized for change point detection in time series.

\subsection{Variability assessment}

Standardized anomalies of time series were analysed by subtracting the mean of the total period to each value and dividing each difference by their standard deviation. To identify potential nonstationary oscillations at different frequencies from the time series, we utilized a wavelet power spectrum with Morlet basis function (Grinsted et al. 2004).

$\mathrm{NAO}, \mathrm{PDO}$ and AMO climate indices were retrieved from LMR reanalysis for the period 1711-2000. A NOAA-ESRL (NOAA Earth System Research Laboratories) 20CR reanalysis- based $\mathrm{NAO}^{1}$ index was also considered for the period 1871-2009. $\mathrm{AMO}^{2}$ and $\mathrm{PDO}^{3}$ indices covering the same period were obtained from NOAA-PSL (NOAA Physical Sciences Laboratory) and NOAA-NCDC (NOAA's National Climatic Data Center), respectively.

The statistical significance of the correlation was assessed using the Ebisuzaki (1997) test (based on MATLAB ${ }^{4}$ ) with 1000 random permutations, which accounts for the autocorrelation of time series.

\section{Results and discussion}

\subsection{Erosivity density reconstruction: analysis of trends}

The results of the model-based ED reconstruction are illustrated in Fig. 4(a), which shows the evolution of the estimated data over the period 1701-2019. The estimated annual ED data values range from 1.1 to $2.9 \mathrm{MJ} \mathrm{h}^{-1} \mathrm{ha}^{-1}$ year $^{-1}$ (circles). Both Buishand and Manley-Whitney-Pettit tests indicate that there is a significant discontinuity $(\mathrm{p}<0.10)$ around the year 1897 (blue curve). The period after the change point (1898-2019) is characterized by increasing ED and extreme values for the 50year (RP50; red curve) and 10-year (RP10; black curve) return periods. Several ED values exceed $2.0 \mathrm{MJ} \mathrm{ha}^{-1} \mathrm{~h}^{-1}$ after the change point. With the 50-year return period (red curve), the ED quantiles go from about $1.5 \mathrm{MJ} \mathrm{ha}^{-1} \mathrm{~h}^{-1}$ year $^{-1}$ at the end of the Little Ice Age ( 1850) up to almost 3.0 MJ ha ${ }^{-1} \mathrm{~h}^{-1}$ year $^{-1}$ afterwards. All seasons except winter contribute to this increasing trend (Table 1), which seems consistent with an increased (seasonally dependent) occurrence of extreme rainfall related to convective processes.

To evaluate the potential origin of these trends, yearly surface air temperature and precipitation rate data from LMR reanalysis were area averaged over Piedmont $\left(44-46^{\circ} \mathrm{N}, 6.5-9.25^{\circ} \mathrm{E}\right)$ and standardized for the period 1701-2000. In Fig. 4(b), they are plotted together with ED and RP50 (RP10 not shown; very similar to RP50). As can be observed, the rising trend in RP50 after the change point (1897) is accompanied by an increase in air temperature in the region, consistent with the ClausiusClapeyron scaling of extreme rainfall by anthropogenic climate change (Trenberth et al. 2003, Westra et al. 2014). A similar behaviour is observed for the surface precipitation rate time series, with an increasing trend along the $20^{\text {th }}$ century, although high values are also present at the beginning of the study period.

For further assessment, convective-rain fluxes from the NASA satellite platform Giovanni were arranged in Fig. 4(c) and (d) for the June to September periods in 1979-1997 and 1998-2015, respectively. The results depict an increase in convective-rain fluxes over the whole of Italy for the more recent period (Diodato et al. 2011), again consistent with an increase in short-term extreme precipitation in a warmer climate. In this sense, it is important to note that extreme precipitation events significantly shape ED time series but may or may not entirely project on yearly/seasonally averaged total precipitation or convective flux amounts. Nonetheless, the

\footnotetext{
1https://psl.noaa.gov/data/20thC_Rean/time series/monthly/NAO/index.htm

${ }^{2}$ https://www.psl.noaa.gov/data/time series/AMO/

${ }^{3} \mathrm{https} / / / \mathrm{www} . n c d c . n o a a . g o v / t e l e c o n n e c t i o n s / p d o /$

${ }^{4} \mathrm{https}: / /$ iri.columbia.edu/ vincent/matlab_function_version1/ebisuzaki.htm
} 
(a)

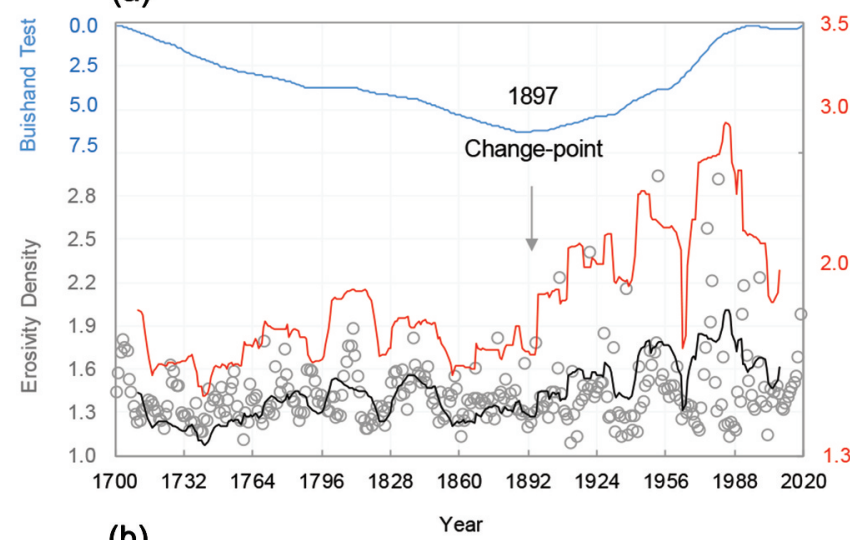

(b)

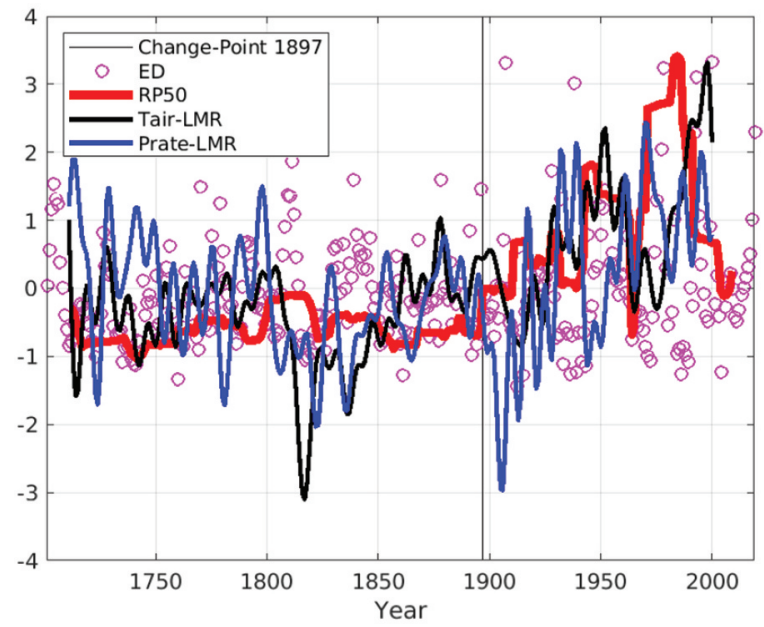

(c)

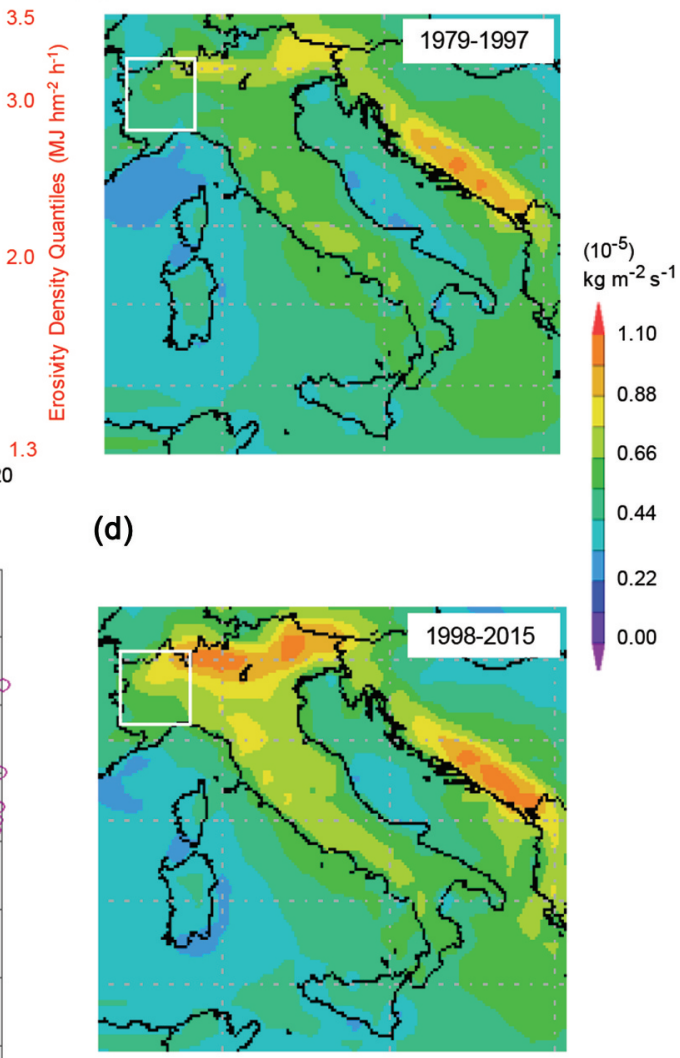

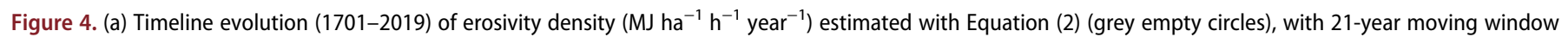

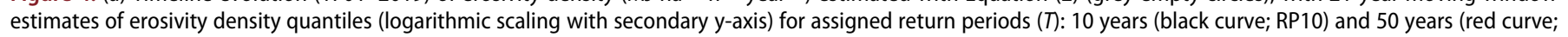
RP50). The Buishand statistic is reported at the top of the chart (blue curve), with estimated change point in the year 1897. (b) Timeline evolution of standardized

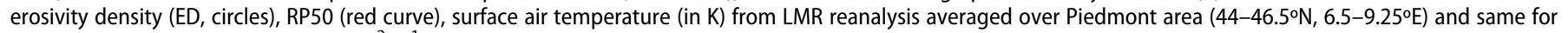

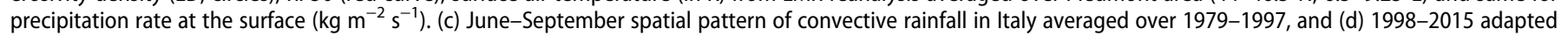
from the Giovanni online data system).

Table 1. Inter-annual coefficients of variation (CV) ranges in each season (for two running mean values of erosivity density) and significance of the Mann-Kendall (M-K) trend test after the breakpoint (year 1897).

\begin{tabular}{lccccc}
\hline & \multicolumn{2}{c}{ 11-year running mean } & & \multicolumn{2}{c}{ 21-year running mean } \\
\cline { 2 - 3 } \cline { 5 - 6 } & $\begin{array}{c}\mathrm{CV} \\
(\text { min-max })\end{array}$ & $\begin{array}{c}\text { M-K trend test } \\
p \text { value }\end{array}$ & & $\begin{array}{c}\mathrm{CV} \\
(\text { min-max })\end{array}$ & $\begin{array}{c}\text { M-K trend test } \\
p \text { value }\end{array}$ \\
\hline Winter & $0.22-0.56$ & $>0.05$ & & $0.27-0.49$ & $>0.05$ \\
Spring & $0.20-0.46$ & $<0.01$ & & $0.23-0.41$ & $<0.01$ \\
Summer & $0.15-0.34$ & $<0.01$ & & $0.18-0.31$ & $<0.01$ \\
Autumn & $0.20-0.59$ & $<0.01$ & & $0.23-0.51$ & $<0.01$ \\
\hline
\end{tabular}

Clausius-Clapeyron scaling hypothesis of extreme rainfall seems consistent with the results obtained in Piedmont, where observed extreme precipitation events have risen in the last two decades for very short (i.e. subhourly) durations (Saidi et al. 2015).

\subsection{Erosivity density reconstruction: analysis of variability}

In addition to the trends, ED and RPs also depict marked variability. In Fig. 4(a), ED roughly oscillates from 1-1.3 to
1.6-1.9 $\mathrm{MJ} \mathrm{ha}^{-1} \mathrm{~h}^{-1}$ values over time (empty grey circles). After the breakpoint year (1897), the coefficient of variation rises from $12 \%$ to $23 \%$. The season that contributes most to this ED variability is autumn (Table 1), when extreme precipitation events occur more frequently in the region (Diodato and Soriano 2014, Acquaotta et al. 2019).

To identify potential oscillatory components in the ED and RP time series, continuous wavelet power spectra were computed (Fig. 5(a,b)), according to Grinsted et al. (2004). Both for ED and RP50 (RP10 is again left out due to a high similarity with RP50), high power spectra are identified in a broad periodicity band (periodicity from 8 to 64 years), with significant values $(p<0.05)$ mainly constrained over the $20^{\text {th }}$ century. Then, correlation values between ED/RP time series and climate (NAO, PDO and AMO) and solar (Hale sunspot cycle) variability indices were computed (Table 2), as they have an important influence on the Euro-Mediterranean climate (Zanchettin et al. 2008b, Diodato and Bellocchi 2014). For the longer period (1711-2000), significant correlation $(p<0.05)$ is only observed between ED and NAO. If a shorter period is considered (1871-2009), coincident with the regions of significant wavelet power spectra in Fig. 5(a,b), more robust 
(a)

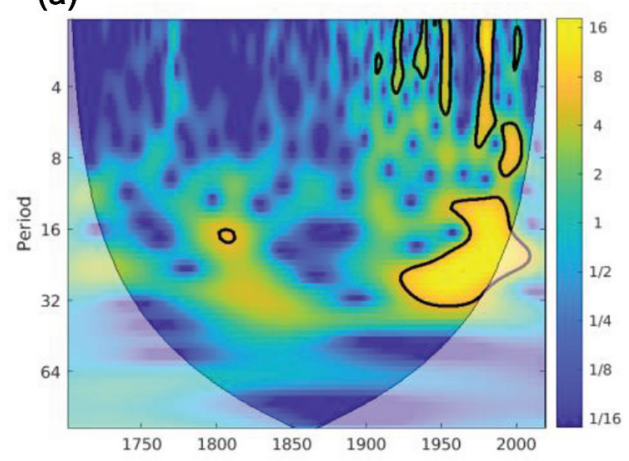

(b)

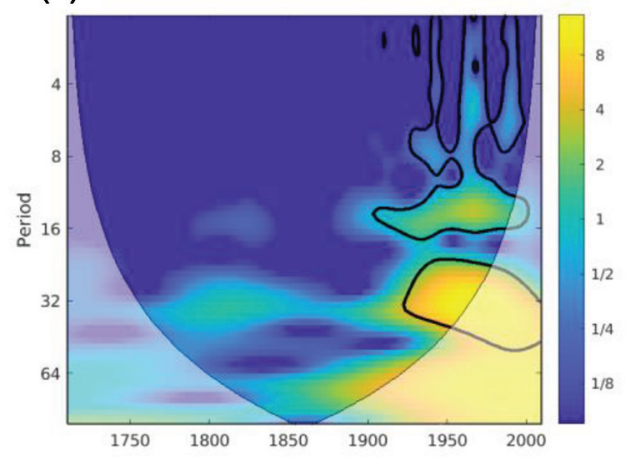

(c)

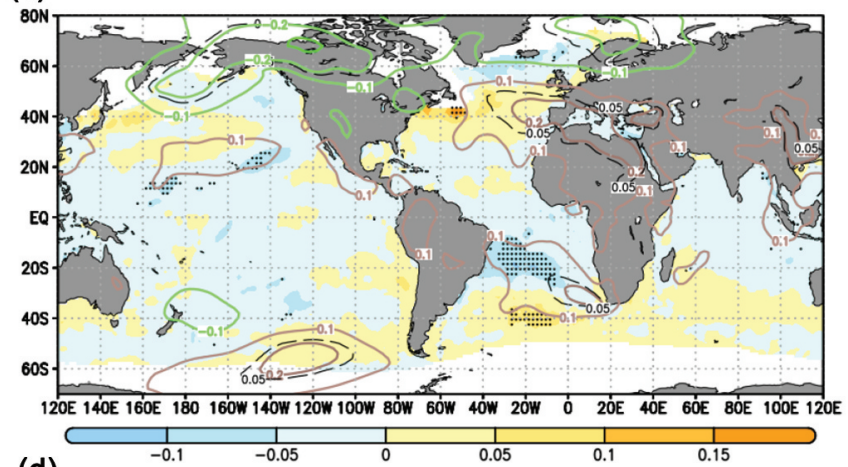

(d)

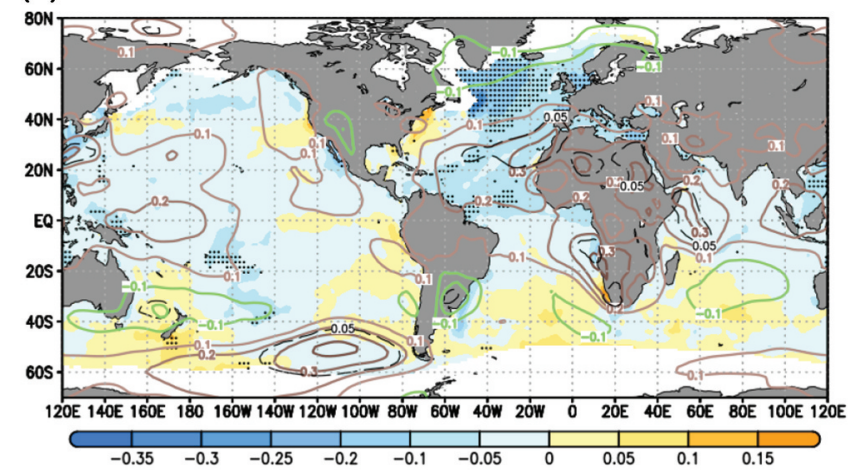

Figure 5. (a) Wavelet power spectrum for erosivity density (ED) time series. Bounded colours identify $p$ values $<0.05$; the bell-shaped contour (cone of influence) marks the limit between the reliable region and the region where the edge effects occur. (b) The same as (a) but for 50-year return period (RP50). (c) Regression of annual SST (shadings; $\mathrm{K} \mathrm{SD}^{-1}$ ) and mslp (contours; $\mathrm{hPa} \mathrm{SD}^{-1}$ ) anomalies on ED, with linear trends removed. For SST, $p<0.05$ values in correlation are shown with black dots. For mslp, the areas with $p<0.05$ are shown with black dashed contours. Period 1871-2009 (HadSST and 20CR V2). (d) The same as (c) but for RP50.

Table 2. Correlation values between climate/solar variability indices and erosivity density (ED) / return period (RP) time series, including description of periods and data sources considered. The $90 \%$ (95\%) confidence interval in correlation (Ebisuzaki test with 1000 random permutations) is indicated with bold (underlined) numbers.

\begin{tabular}{|c|c|c|c|c|c|}
\hline Correlation & Period & Database & ED & RP10 & RP50 \\
\hline AMO & $1711-2000 / 1871-2009$ & LMR/NOAA-PSL & $-0.04 /-0.07$ & $-0.16 /-0.43$ & $-0.16 /-0.50$ \\
\hline NAO & $1711-2000 / 1871-2009$ & LMR/20CR & $0.16 / 0.16$ & $0.08 / \mathbf{0 . 3 0}$ & $0.06 / \underline{0.31}$ \\
\hline PDO & 1711-2000/1871-2009 & LMR/NOAA-NCDC & $-0.08 /-0.03$ & $0.11 /-0.01$ & $\begin{array}{l}0.12 / 0.04 \\
* / 023\end{array}$ \\
\hline Hale cycle & */1901-2009 & */ISGI & */0.10 & */0.34 & */0.33 \\
\hline Sunspot & $1711-2000 / 1871-2009$ & SILSO/SILSO & $0.03 / 0.04$ & $0.09 / 0.17$ & $0.06 / 0.16$ \\
\hline
\end{tabular}

statistical links are observed between all ED/RP time series and $\mathrm{NAO}$, and RP time series with AMO. The observed correlation between RPs and the Hale cycle is also high for the most recent period, but autocorrelation of the time series prevents these values from being statistically significant (Ebisuzaki test: $p<0.05)$.

To further investigate these statistical relationships, annual SST and mean sea level pressure (mslp) anomalies from HadSST and 20CR were regressed on ED and RP50 time series for the period 1871-2009. For ED (Fig. 5(c)), a NAO-like dipole of significant mslp anomalies is present over the North Atlantic, with positive values over the eastern subtropical North Atlantic and Mediterranean regions and negative over subpolar areas. Regression of SST anomalies onto ED does not return any clear output, consistent with the results shown in Table 2. For RP50 (Fig. 5(d)), a similar NAO-like pattern is observed in the mslp anomaly regression field, accompanied by significant negative SST anomalies over the
North Atlantic and Mediterranean Sea. The obtained SST pattern resembles the negative phase of the AMO.

Regarding AMO and Mediterranean precipitation, Sutton and Dong (2012) identified an increase of precipitation over Mediterranean areas under negative AMO phases. However, this relation was found for average seasonal rainfall. Regarding extremes, Casanueva et al. (2014) identified an increase of events over the central and eastern Mediterranean under positive NAO phases in summer. In the light of the results presented here, a much deeper analysis may be needed to identify the underlying physical mechanisms between NAO, AMO and extreme precipitation over Piedmont. As the synoptic largescale atmospheric setup fostering these events (e.g. cut-off low occurrence with low-level moisture advection from the Mediterranean) may or may not project onto monthly/annual means of physical variables, a frequency analysis of daily weather regimes may be needed (Zampieri et al. 2017), with a focus on precipitation extremes over Piedmont. An analysis 
of the nonstationary relation between climate teleconnection patterns (e.g. AMO) and impact variables (ED) may also be needed, in line with previous findings on this topic for the Euro-Mediterranean region (Greatbatch et al. 2004, LópezParages and Rodríguez-Fonseca 2012, Gómara et al. 2016). Since such analyses are beyond the scope of this paper, they are left for further research.

\subsection{Regional change perspective on rainfall erosivity}

Numerous flood events have occurred since the 18th century in Piedmont, with a 2- to 3-year frequency for minor events. In recent times, important hydrological events have also taken place in northern Italy (Saidi et al. 2013). In line with our results, detailed analyses performed in Piedmont have provided evidence of changes in the intra-annual distribution of precipitation. In fact, Acquaotta et al. (2019) and Baronetti et al. (2020) identified an increase in the length of periods characterized by consecutive dry days, and more intense and frequent extreme precipitation events. An intensification of extreme events was recorded in Piedmont since the end of 1990s, with the Po River basin being the most vulnerable area.

The estimated annual rainfall erosivity for Piedmont in the period 1701-2019 ranged from a minimum of $903 \mathrm{MJ} \mathrm{mm} \mathrm{ha}^{-1}$ $\mathrm{h}^{-1}$ year $^{-1}$ (year 1989) to a maximum of $3626 \mathrm{MJ} \mathrm{mm} \mathrm{ha} \mathrm{hm}^{-1} \mathrm{~h}^{-1}$ year $^{-1}$ (year 1976), with an average of $1769 \mathrm{MJ} \mathrm{mm} \mathrm{ha}{ }^{-1} \mathrm{~h}^{-1}$ year $^{-1}$. The highest values $\left(>3000 \mathrm{MJ} \mathrm{mm} \mathrm{ha}{ }^{-1} \mathrm{~h}^{-1}\right.$ year $\left.^{-1}\right)$ all occurred in the second half of the $20^{\text {th }}$ century, i.e. 3241,3365 , 3383,3387 and $3626 \mathrm{MJ} \mathrm{mm} \mathrm{ha}{ }^{-1} \mathrm{~h}^{-1}$ year $^{-1}$ in the years 1981, 1953, 2000, 1977 and 1976, respectively. For the same period, Panagos et al. (2015) showed an increased exposure to erosive rainfall for several European countries (including Mediterranean countries). Acquaotta et al. (2019) also confirmed an upward erosivity trend for the period 1981-2015 in much of northern Italy. This increasing trend, together with increased inter-annual variability, is in fact a continuous process of precipitation intensification in Northern Italy, which began in the 1700s, likely associated with an increase in the frequency of extreme short-term rainfall events (Diodato et al. 2020b). This means that northern Italy has been exposed to a progressively increasing inter-annual variability in rainfall erosivity, resulting in an increased hazardous landscape stress. This has likely caused increased runoff and sediment losses throughout Piedmont, mostly concentrated in autumn (Biddoccu et al. 2016), associated with a decline in wine grape production (Capello et al. 2020).

The Po Plain is a subsiding sedimentary basin that hosts the majority of the Piedmontese population and $40 \%$ of its productive activities (Zanchettin et al. 2008a). The Corine Land Cover project (EEA 2010) has highlighted an important change since the 2000s, with artificial surfaces increasing at the detriment of agricultural, woody and semi-natural areas. Such recent changes in the land-use coverage have made the Po Valley more vulnerable to floods due to extreme precipitation episodes. The two most intensive floods of the Po River were recorded in November 1994, where heavy precipitation occurred in the whole basin and daily total precipitation exceeded $200 \mathrm{~mm}$ for 5 consecutive days (Marchi et al. 1995). In October 2000, much of the basin area experienced heavy precipitation values larger than $600 \mathrm{~mm}$ in $96 \mathrm{~h}$, damaging both the mountainous area and part of the town of Turin (Gabella and Mantonvani 2001). Remarkable also was the flood episode of November 2016, which involved not only the Po River but also its tributaries. Daily heavy precipitation events of about $300 \mathrm{~mm}$ were observed in the whole basin (Giordan et al. 2018). Coppola and Giorgi (2010) predicted a marked future decrease of precipitation in winter and summer in north Italy, while a slight increase in autumn is expected. Brogli et al. (2019) showed that precipitation quantiles are expected to increase in northern Italy, where more extended dry periods and extreme precipitation episodes will likely be experienced because of drier summer conditions.

An increase in the hazard values in the decades to come, associated with increased extreme rainfall in northwest Italy, appears compatible with an increasing atmospheric moisture content in a warming climate (according to the ClausiusClapeyron equation). A range of factors, such as temperature lapse rate, convective available potential energy and low-level moisture availability, would modulate extreme events when they occur (Pfahl et al. 2017). While our results for the historical period are compatible (in terms of trends) with projection studies on extreme precipitation for the decades to come (Rajczak et al. 2013, Giorgi et al. 2016), some results that contrast with rainfall-erosivity projections in northern Italy must be also highlighted (Panagos et al. 2017b). Since different analyses can change perceptions of the type of hazard associated with hydrological processes when using dissimilar metrics, in this study we advocate the use of ED, which reflects not only the climate-forcing component reproduced in the prevailing storm aggressiveness (erosivity) but also the damaging hydrologic hazard. ED-based metrics offer this opportunity because regions with high ED values are exposed to a risk of flooding (and even water scarcity) because of their infrequent but very intense and erosive rainstorms (Diodato et al. 2019).

\section{Conclusions}

The present study offers the evaluation of a novel model of erosivity density (ED) calculation, and its associated 10-year and 50-year return periods (RPs), for the westernmost region of northern Italy, which were used to quantitatively assess the variation of interdecadal erosivity density in the same area. It reveals the propagation of a wetting front resulting in highenergy rainfall and provides essential information to understand storm-related phenomena in the Piedmont region. The results imply that a future increase in land-use intensity and extreme precipitation events might have severe consequences regarding soil erosion, flash-flood risk and ecological disruption.

For the multicentennial assessment performed in this work, the two main conclusions are as follows. First, annual ED (and RP) values across the Piedmont region show stormier and more changeable weather after 1897, which appears consistent with the Clausius-Clapeyron scaling of extreme rainfall. Second, a robust link between ED and the North Atlantic Oscillation (NAO) was found for both the complete (1711-2000) and recent (1871-2009) periods. For the latter, a significant opposite-phase link between the Atlantic 
Multidecadal Oscillation (AMO) and the RP time series was also identified.

The present analysis, performed at an annual scale, may mask important variations manifesting at finer time scales. Daily and subdaily to seasonal changes may in fact affect hydrology and land conditions, while the methodology applied in this study is mostly appropriate to address ED variations occurring at interannual to interdecadal time scales. Our regional reconstruction of continuous yearly ED data is important not only for climate analyses at decadal and centennial time scales, but also to derive climatology for hydrologic models requiring erosivity data as forcing input. Supported by complementary studies on extreme precipitation in northern Italy, the methodology is robust and provides essential elements to plan actions to prevent, mitigate, prepare for, respond to and recover from the effects of floods and other water-related disasters in Piedmont.

Even so, caution must be exercised in statistically relating large-scale climate indices to hydro-climatic variables such as hydrological extremes occurring locally on subhourly scales. Stimulating the debate about a better understanding of the climate mechanisms behind the onset and persistence of temporally discontinuous and chaotic rainfall events may help us advance in improving decadal climate predictions. Prospective studies focused on hazardous hydrological processes are needed, in which the intensification of the increasing atmospheric moisture content in a warming climate is taken into account as well as the oscillations induced by atmospheric and ocean forcing agents. In conclusion, our results imply that environmental management can use data from long historical time series as a reference for decision-making, although the relationships between variability indices, like the NAO and the AMO, and extreme rainfall patterns need to be substantiated beyond our study area to better infer their underlying dynamics. Since geographical locations have characteristics that require specific model structures and local optimization, then the application of the model over other regions may be limited by the ability to provide representative drivers and parameter values. However, our results suggest that the parsimonious principle used in this study is sufficiently robust and may be suitable for a spatial generalization over the Mediterranean region, whose climate is dominated by Atlantic influences (Diodato et al. 2020a).

\section{Disclosure statement}

No potential conflict of interest was reported by the authors.

\section{Funding}

$\mathrm{ND}, \mathrm{GB}$ and IG performed this research as an investigator-driven study without financial support. $\mathrm{AB}$ developed this study during her $\mathrm{PhD}$ at University of Turin (Italy).

\section{ORCID}

Nazzareno Diodato (D) http://orcid.org/0000-0001-9549-1583 Iñigo Gómara (D) http://orcid.org/0000-0001-8721-0307 Alice Baronetti (iD http://orcid.org/0000-0001-8576-4795 Simona Fratianni (iD) http://orcid.org/0000-0002-8706-882X Gianni Bellocchi (iD) http://orcid.org/0000-0003-2712-7979

\section{Availability of data, material and code}

Long-term precipitation reconstruction dataset from Pauling et al. (2006): ftp://ftp.ncdc.noaa.gov/pub/data/ghcn/v3; CRU Global Climate Dataset: http://www.cru.uea.ac.uk/data; NASA satellite platform Giovanni webbased application: http://disc.sci.gsfc.nasa.gov/giovanni; Total sunspot numbers from Sunspot Index and Long-term Solar Observations: http:// www.sidc.be/silso/datafiles; International Service of Geomagnetic Indices: http://isgi.unistra.fr; Last Millennium Reanalysis (LMR) Project Global Climate Reconstructions Version 2: https://www.ncdc.noaa.gov/paleosearch/study/27850; NOAA-CIRES-DOE for the Twentieth Century Reanalysis (20CR): https://www.esrl.noaa.gov/psd/data/20thC_Rean; Met Office Hadley centre for the HadSST database: https://www.metof fice.gov.uk/hadobs/hadsst4; Global Land One-kilometre Base Elevation (GLOBE) v.1: doi:10.7289/V52R3PMS;. Additional data and codes available from the authors upon request

\section{Authors' contributions}

Conceptualization, methodological design and preparation of Figs. 1-4 were carried out by ND and GB. Figures 4(b) and 5 were prepared by IG. AB and SF put the modelling approach into the context of regional hydrology. All coauthors reviewed and contributed to the final version of the manuscript.

\section{References}

Acquaotta, F., et al., 2019. Estimation of rainfall erosivity in Piedmont (Northwestern Italy) by using 10-minute fixed-interval rainfall data. IDÖJÁRÁS, 123 (1), 18. doi:10.28974/idojaras.2019.1.1

Arnaez, J., et al., 2007. Factors affecting runoff and erosion under simulated rainfall in Mediterranean vineyards. Soil and Tillage Research, 93 (2), 324-334. doi:10.1016/j.still.2006.05.013

Aronica, G. and Ferro, V., 1997. Rainfall erosivity over the Calabrian region. Hydrological Sciences Journal, 42 (1), 35-48. doi:10.1080/ 02626669709492004

Baronetti, A., et al., 2020. A weekly spatio-temporal distribution of drought events over the Po Plain (North Italy) in the last five decades. International Journal of Climatology, 40 (10), 4463-4476. doi:10.1002/joc.6467

Baronetti, A., Acquaotta, F., and Fratianni, S., 2018. Rainfall variability from a dense rain gauge network in north-western Italy. Climate Research, 75 (3), 201-213. doi:10.3354/cr01517

Biddoccu, M., et al., 2016. Long-term monitoring of soil management effects on runoff and soil erosion in sloping vineyards in Alto Monferrato (North-West Italy). Soil and Tillage Research, 155, 176-189. doi:10.1016/j.still.2015.07.005

Blöschl, G., et al., 2020. Current European flood-rich period exceptional compared with past 500 years. Nature, 583 (7817), 560-566. doi:10.1038/s41586-020-2478-3

Boardman, J. and Poesen, J., 2006. Soil erosion in Europe: major processes, causes and consequences. In: J. Boardman and J. Poesen, eds. Soil erosion in Europe, Chichester, UK: John Wiley \& Sons, 477-487.

Brogli, R., et al., 2019. Causes of future Mediterranean precipitation decline depend on the season. Environmental Research Letters, 14 (11), 114017. doi:10.1088/1748-9326/ab4438

Brönnimann, S., Pfister, C., and White, S., 2018. Archives of nature and archives of societies. In: S. White, C. Pfister, and F. Mauelshagen, eds. The Palgrave handbook of climate history. London: Palgrave Macmillan UK, 27-36.

Brown, L.C. and Foster, G.R., 1987. Storm erosivity using idealized intensity distributions. Transactions of the ASABE, 30 (2), 379-386. doi:10.13031/2013.31957

Buishand, T.A., 1982. Some methods for testing the homogeneity of rainfall records. Journal of Hydrology, 58 (1), 11-27. doi:10.1016/ 0022-1694(82)90066-X

Capello, G., Biddoccu, M., and Cavallo, E., 2020. Permanent cover for soil and water conservation in mechanized vineyards: a study case in Piedmont, NW Italy. Italian Journal of Agronomy, 15 (4), 323-331. doi:10.4081/ija.2020.1763 
Casanueva, A., et al., 2014. Variability of extreme precipitation over Europe and its relationships with teleconnection patterns. Hydroogy Earth System Sciences, 18 (2), 709-725.

Castellano, M.J., et al., 2019. Sustainable intensification of agricultural drainage. Nature Sustainability, 2 (10), 914-921. doi:10.1038/s41893019-0393-0

Compo, G.P., et al., 2011. The twentieth century reanalysis project. Quarterly Journal of the Royal Meteorological Society, 137 (654), 1-28. doi:10.1002/qj.776

Coppola, E. and Giorgi, F., 2010. An assessment of temperature and precipitation change projections over Italy from recent global and regional climate model simulations. International Journal of Climatology, 30 (1), 11-32. doi:10.1002/joc.1867

Corella, J.P., et al., 2016. Three millennia of heavy rainfalls in Western Mediterranean: frequency, seasonality and atmospheric drivers. Scientific Reports, 6 (1), 38206. doi:10.1038/srep38206

Corti, G., et al., 2011. Evaluation of erosion intensity and some of its consequences in vineyards from two hilly environments under a Mediterranean type of climate, Italy. In: D. Godone and S. Stanchi, eds. Soil erosion issues in agriculture. London: InTechOpen, 114-160.

D' Odorico, P., Yoo, J.C., and Over, T.M., 2001. An assessment of ENSO-induced patterns of rainfall erosivity in the Southwestern United States. Journal of Climate, 14 (21), 4230-4242. doi:10.1175/ 1520-0442(2001)014<4230:AAOEIP>2.0.CO;2

Diakhaté, M., et al., 2019. Oceanic forcing on interannual variability of sahel heavy and moderate daily rainfall. Journal of Hydrometeorology, 20 (3), 397-410. doi:10.1175/JHM-D-18-0035.1

Diodato, N., 2004. Estimating RUSLE's rainfall factor in the part of Italy with a Mediterranean rainfall regime. Hydrology and Earth System Sciences, 8 (1), 103-107. doi:10.5194/hess-8-103-2004

Diodato, N., et al., 2011. How the aggressiveness of rainfalls in the Mediterranean lands is enhanced by climate change. Climatic Change, 108 (3), 591. doi:10.1007/s10584-011-0216-4

Diodato, N. and Soriano, M., 2014. Rainfalls and storm erosivity. In: N. Diodato and G. Bellocchi, eds. Storminess and environmental change: climate forcing and responses in the Mediterranean region. Dordrecht: Springer Netherlands, 39-51.

Diodato, N. and Bellocchi, G., 2010. Storminess and environmental changes in the Mediterranean Central Area. Earth Interactions, 14 (5), 1-16. doi:10.1175/2010EI306.1

Diodato, N. and Bellocchi, G., 2014. Storminess and environmental change: climate forcing and responses in the Mediterranean region. Netherlands: Springer.

Diodato, N., Ljungqvist, F.C., and Bellocchi, G., 2019. A millennium-long reconstruction of damaging hydrological events across Italy. Scientific Reports, 9 (1), 9963. doi:10.1038/s41598-019-46207-7

Diodato, N., Ljungqvist, F.C., and Bellocchi, G., 2020a. Fingerprint of climate change in precipitation aggressiveness across the central Mediterranean (Italian) area. Scientific Reports, 10 (1), 22062. doi:10.1038/s41598-020-78857-3

Diodato, N., Ljungqvist, F.C., and Bellocchi, G., 2020b. Historical predictability of rainfall erosivity: a reconstruction for monitoring extremes over Northern Italy (1500-2019). npj Climate and Atmospheric Science, 3 (1), 46. doi:10.1038/s41612-020-00144-9

Diodato, N., Ljungqvist, F.C., and Bellocchi, G., 2020c. Monthly storminess over the Po River Basin during the past millennium (800-2018 CE). Environmental Research Communications, 2 (3), 031004. doi:10.1088/2515-7620/ab7ee9

Durbin, J. and Watson, G.S., 1950. Testing for serial correlation in least squares regression. I. Biometrika, 37 (3-4), 409-428.

Durbin, J. and Watson, G.S., 1951. Testing for serial correlation in least squares regression. II. Biometrika, 38 (1-2), 159-178. doi:10.1093/ biomet/38.1-2.159

Ebisuzaki, W., 1997. A method to estimate the statistical significance of a correlation when the data are serially correlated. Journal of Climate, 10 (9), 2147-2153. doi:10.1175/1520-0442(1997)010<2147:AMTETS >2.0. $\mathrm{CO} ; 2$

Eea, 2010. Corine land cover. European Environment Agency. Available from: https://www.eea.europa.eu/publications/COR0-landcover [Accessed 1 Oct 2020].
Fratianni, S. and Acquaotta, F., 2017. The climate of Italy. In: M. Soldati and M. Marchetti, eds. Landscapes and landforms of Italy. Cham, Switzerland: Springer International Publishing, 29-38.

Fratianni, S., Cassardo, C., and Cremonini, R., 2009. Climatic characterization of foehn episodes in Piedmont, Italy. Geografia Fisica e Dinamicca Quaternaria, 32, 15-22.

Gabella, M. and Mantonvani, R., 2001. The floods of 13-16 October 2000 in Piedmont (Italy): quantitative precipitation estimates using radar and a network of gauges. Weather, 56 (10), 337-343. doi:10.1002/ j.1477-8696.2001.tb06505.x

Giordan, D., et al., 2018. Low cost, multiscale and multi-sensor application for flooded area mapping. Natural Hazards and Earth System Sciences, 18 (5), 1493-1516. doi:10.5194/nhess-181493-2018

Giorgi, F., et al., 2016. Enhanced summer convective rainfall at Alpine high elevations in response to climate warming. Nature Geoscience, 9 (8), 584-589. doi:10.1038/ngeo2761

Gjelten, H.M., et al., 2016. Air temperature variations and gradients along the coast and fjords of western Spitsbergen. Polar Research, 35 (1), 1. doi:10.3402/polar.v35.29878

Gómara, I., et al., 2016. Abrupt transitions in the NAO control of explosive North Atlantic cyclone development. Climate Dynamics, 47 (9), 3091-3111. doi:10.1007/s00382-016-3015-9

Gómara, I., et al., 2018. Impact of dynamical regionalization on precipitation biases and teleconnections over West Africa. Climate Dynamics, 50 (11), 4481-4506. doi:10.1007/s00382-017-3886-4

Granger, C.W.J., Hyung, N., and Jeon, Y., 2001. Spurious regressions with stationary series. Applied Economics, 33 (7), 899-904. doi:10.1080/ 00036840121734

Greatbatch, R.J., Lu, J., and Peterson, K.A., 2004. Nonstationary impact of ENSO on Euro-Atlantic winter climate. Geophysical Research Letters, 31 (2), L02208. doi:10.1029/2003GL018542

Grinsted, A., Moore, J., and Jevrejeva, S., 2004. Application of cross wavelet transform and wavelet coherence to geophysical time series. Nonlinear Processes in Geophysics, 11 (5/6), 561-566. doi:10.5194/npg11-561-2004

Hale, G.E., et al., 1919. The magnetic polarity of sun-spots. The Astrophysical Journal, 49, 153-178. doi:10.1086/142452

Hale, G.E. and Nicholson, S.B., 1938. Magnetic observations of sunspots, 1917-1924. Carnegie Institution of Washington Publication.

Harris, C., et al., 2003. Warming permafrost in European mountains. Global and Planetary Change, 39 (3), 215-225. doi:10.1016/j. gloplacha.2003.04.001

Harris, I., et al., 2020. Version 4 of the CRU TS monthly high-resolution gridded multivariate climate dataset. Scientific Data, 7 (1), 109. doi:10.1038/s41597-020-0453-3

Harris, R.M.B., et al., 2018. Biological responses to the press and pulse of climate trends and extreme events. Nature Climate Change, 8 (7), 579-587. doi:10.1038/s41558-018-0187-9

Hawcroft, M.K., et al., 2012. How much Northern Hemisphere precipitation is associated with extratropical cyclones?. Geophysical Research Letters, 39 (24), L24809. doi:10.1029/2012GL053866

ISTAT, 2020. Instituto Nazionale di Statistica - Agriculture. Availabe from: http://dati.istat.it/Index.aspx?QueryId=37850\&lang=en [Accessed 1 Oct 2020]

Kendall, M.G., 1975. Rank Correlation Methods. 4th Edition, Charles Griffin, London, UK

Li, Z. and Fang, H., 2016. Impacts of climate change on water erosion: a review. Earth-Science Reviews, 163, 94-117. doi:10.1016/j. earscirev.2016.10.004

Longman, J., et al., 2019. Runoff events and related rainfall variability in the Southern Carpathians during the last 2000 years. Scientific Reports, 9 (1), 5334. doi:10.1038/s41598-019-41855-1

López-Parages, J. and Rodríguez-Fonseca, B., 2012. Multidecadal modulation of El Niño influence on the Euro-Mediterranean rainfall. Geophysical Research Letters, 39 (2), L02704. doi:10.1029/2011GL050049

Marchi, E., Roth, G., and Siccardi, F., 1995. The November 1994 flood event on the Po River: structural and non-structural measures against inundations. Perugia: US-Italy Research Workshop on the Hydrometeorology, Impacts, and Management of Extreme Floods. 
Millares, A. and Moñino, A., 2020. Hydro-meteorological drivers influencing suspended sediment transport and yield in a semi-arid mountainous basin. Earth Surface Processes and Landforms, 45 (15), 3791-3807. doi:10.1002/esp.5001

Oddone, M., et al., 2009. Authentication and traceability study of hazelnuts from Piedmont, Italy. Journal of Agricultural and Food Chemistry, 57 (9), 3404-3408. doi:10.1021/jf900312p

Panagos, P., et al., 2015. Rainfall erosivity in Europe. Science of the Total Environment, 511, 801-814. doi:10.1016/j.scitotenv.2015.01.008

Panagos, P., et al., 2017a. Global rainfall erosivity assessment based on high-temporal resolution rainfall records. Scientific Reports, 7 (1), 4175. doi:10.1038/s41598-017-04282-8

Panagos, P., et al., 2017b. Towards estimates of future rainfall erosivity in Europe based on REDES and WorldClim datasets. Journal of Hydrology, 548, 251-262. doi:10.1016/j.jhydrol.2017.03.006

Pauling, A., et al., 2006. Five hundred years of gridded high-resolution precipitation reconstructions over Europe and the connection to large-scale circulation. Climate Dynamics, 26 (4), 387-405. doi:10.1007/s00382-0050090-8

Perrier, F., et al., 2005. Long-term climate change and surface versus underground temperature measurements in Paris. International Journal of Climatology, 25 (12), 1619-1631. doi:10.1002/joc.1211

Pettitt, A.N., 1979. A non-parametric approach to the change-point problem. Journal of the Royal Statistical Society. Series C, Applied Statistics, 28 (2), 126-135.

Pfahl, S., O' Gorman, P.A., and Fischer, E.M., 2017. Understanding the regional pattern of projected future changes in extreme precipitation. Nature Climate Change, 7 (6), 423-427. doi:10.1038/nclimate3287

Pfister, C., White, S., and Mauelshagen, F., 2018. General introduction: weather, climate, and human history. In: S. White, C. Pfister, and F. Mauelshagen, eds. The Palgrave handbook of climate history. London: Palgrave Macmillan UK, 1-17.

Piñeiro, V., et al., 2020. A scoping review on incentives for adoption of sustainable agricultural practices and their outcomes. Nature Sustainability, 3 (10), 809-820. doi:10.1038/s41893-020-00617-y

Pinna, M., 1978. L'atmosfera e il clima. Turin: UTET.

Pinto, J., et al., 2001. Extreme precipitation events over north-west Italy and their relationship with tropical-extratropical interactions over the Atlantic. In:Proceedings of third EGS Plinius conference on Mediterranean storms, Baja Sardinia, 321-332.

Pinto, J.G. and Raible, C.C., 2012. Past and recent changes in the North Atlantic oscillation. WIREs Climate Change, 3 (1), 79-90. doi:10.1002/wcc.150

Prosdocimi, M., Cerdà, A., and Tarolli, P., 2016. Soil water erosion on Mediterranean vineyards: a review. CATENA, 141, 1-21.

Quinton, J., 2004. Erosion and sediment transport. In: J. Wainwright, ed. Finding simplicity in complexity. Oxford: John Wiley \& Sons, 187-196.

Rajczak, J., Pall, P., and Schär, C., 2013. Projections of extreme precipitation events in regional climate simulations for Europe and the Alpine region. Journal of Geophysical Research: Atmospheres, 118 (9), 3610-3626.

Rayner, N.A., et al., 2003. Global analyses of sea surface temperature, sea ice, and night marine air temperature since the late nineteenth century. Journal of Geophysical Research: Atmospheres, 108 (D14), 4407. doi:10.1029/2002JD002670

Renard, K.G., et al., 1997. Predicting soil erosion by water: a guide to conservation planning with the Revised Universal Soil Loss Equation (RUSLE). Washington: US Government Printing Office.

Renard, K.G., et al., 2011. Universal soil loss equation and revised universal soil loss equation. In: R.P.C. Morgan and M.A. Nearing, eds. Handbook of Erosion Modelling, 135-167. Chichester, UK: John Wiley \& Sons Ltd.

Renard, K.G. and Freimund, J.R., 1994. Using monthly precipitation data to estimate the R-factor in the revised USLE. Journal of Hydrology, 157 (1), 287-306. doi:10.1016/0022-1694(94)90110-4
Rubel, F., et al., 2017. The climate of the European Alps: shift of very high resolution Köppen-Geiger climate zones 1800-2100. Meteorologische Zeitschrift, 26 (2), 115-125. doi:10.1127/metz/2016/0816

Saidi, H., et al., 2013. The climatic characteristics of extreme precipitations for short-term intervals in the watershed of Lake Maggiore. Theoretical and Applied Climatology, 113 (1), 1-15. doi:10.1007/ s00704-012-0768-x

Saidi, H., et al., 2015. Assessment of trends in extreme precipitation events: a case study in Piedmont (North-West Italy). Water Resources Management, 29 (1), 63-80. doi:10.1007/s11269-014-0826-5

Sutton, R.T. and Dong, B., 2012. Atlantic Ocean influence on a shift in European climate in the 1990s. Nature Geoscience, 5 (11), 788-792. doi:10.1038/ngeo1595

Tardif, R., et al., 2019. Last Millennium Reanalysis with an expanded proxy database and seasonal proxy modeling. Climate of the Past, 15 (4), 1251-1273. doi:10.5194/cp-15-1251-2019

Taricco, C., et al., 2015. Marine sediments remotely unveil long-term climatic variability over Northern Italy. Scientific Reports, 5 (1), 12111. doi:10.1038/srep12111

Taszarek, M., et al., 2018. Climatological aspects of convective parameters over Europe: a comparison of ERA-Interim and sounding data. Journal of Climate, 31 (11), 4281-4308. doi:10.1175/JCLI-D-17-0596.1

Trenberth, K.E., et al., 2003. The changing character of precipitation. Bulletin of the American Meteorological Society, 84 (9), 1205-1218. doi:10.1175/BAMS-84-9-1205

Wei, W., Liding, C., and Bojie, F., 2009. Effects of rainfall change on water erosion processes in terrestrial ecosystems: a review. Progress in Physical Geography: Earth and Environment, 33 (3), 307-318. doi:10.1177/0309133309341426

Westra, S., et al., 2014. Future changes to the intensity and frequency of short-duration extreme rainfall. Reviews of Geophysics, 52 (3), 522-555.

Wetter, O., et al., 2011. The largest floods in the High Rhine basin since 1268 assessed from documentary and instrumental evidence. Hydrological Sciences Journal, 56 (5), 733-758. doi:10.1080/ 02626667.2011.583613

Willems, P., 2013. Multidecadal oscillatory behaviour of rainfall extremes in Europe. Climatic Change, 120 (4), 931-944. doi:10.1007/s10584013-0837-x

Willmott, C.J., 1981. On the validation of models. Physical Geography, 2 (2), 184-194. doi:10.1080/02723646.1981.10642213

Wischmeier, W.H. and Smith, D.D., 1978. Predicting rainfall erosion losses: a guide to conservation planning. Department of Agriculture, Science and Education Administration. Hyattsville, Maryland.

Wuepper, D., Borrelli, P., and Finger, R., 2020. Countries and the global rate of soil erosion. Nature Sustainability, 3 (1), 51-55. doi:10.1038/ s41893-019-0438-4

Yin, J., et al., 2018. Large increase in global storm runoff extremes driven by climate and anthropogenic changes. Nature Communications, 9 (1), 4389. doi:10.1038/s41467-018-06765-2

Zampieri, M., et al., 2017. Atlantic multi-decadal oscillation influence on weather regimes over Europe and the Mediterranean in spring and summer. Global and Planetary Change, 151, 92-100. doi:10.1016/j. gloplacha.2016.08.014

Zanchettin, D., et al., 2008a. Impact of variations in solar activity on hydrological decadal patterns in northern Italy. Journal of Geophysical Research: Atmospheres, 113 (D12), D12102. doi:10.1029/ 2007JD009157

Zanchettin, D., Traverso, P., and Tomasino, M., 2008b. Po River discharges: a preliminary analysis of a 200-year time series. Climatic Change, 89 (3-4), 411-433. doi:10.1007/s10584-0089395-Z 